\title{
GYPA wt Allele
}

National Cancer Institute

\section{Source}

National Cancer Institute. GYPA wt Allele. NCI Thesaurus. Code C52348.

Human GYPA wild-type allele is located within 4q28.2-q31.1 and is approximately $31 \mathrm{~kb}$ in length. This allele, which encodes glycophorin A protein, is involved in the antigenic determination of $\mathrm{M} / \mathrm{N}$ and $\mathrm{S} / \mathrm{s}$ blood groups. 